10. Повышение качества и расширение сортамента закаленных рельсов из конвертерной стали / А. С. Рудюк, А. А. Азаркевич, А. Д. Лебедев и др. / / Металл и литье Украины. - 2013. № 6. - C. 25-29.

Rudyuk A. S., Azarkevich A. A., Lebedev A. D. Pooyshenie kachestoa i rasshirenie sortamenta zakalennykh rel'sov iz konverternoy stali. Metall i lit'e Ukrainy. 2013, no. 6, pp. 25-29.

11. Металлургические микрозаводы - решение проблемы производства фасонного проката малотоннажными партиями / С. Г. Грищенко, Д. В. Сталинский, А. С. Рудюк, В. С. Медведев // Сталь. - 2008. - № 9. - С. 53-56.

Grishchenko S. G., Stalinskiy D. V., Rudyuk A. S., Medvedev V. S. Metallurgicheskie mikrozavody reshenie problemy proizvodstva fasonnogo prokata malotonnazhnymi partiyami. Stal. 2008, no. 9, pp. 53-56.

Розглянуто етапи становлення та розвитку Українського науково-дослідного інституту металів (УкрНДІМет), створеного 30 жовтня 1928 р. для надання науково-технічної допомоги підприємствам металургійної галузі. Протягом 90 років інститут перебуває на передових рубежах металуреії, удосконалюючи діючі і розробляючи нові ефективні технології для всіх металургійних переділів. На цей час УкрНДІМет входить до складу ДП «УкрНТЦ «Енергосталь» та, зберігаючи багаторічні традиції, націлений на успішну реалізацію нових проектів у сорері металургійного виробництва, енерго- $i$ ресурсозбереження, використання вторинних енергоресурсів і захисту навколишнього природного середовища.

Ключові слова: чорна металургія, сталь, чавун, безперервне розливання сталі, елементи верхньої будови залізничної колії, профрілі металопрокату, що мелють тіла, стандартизація.

The formation and development stages of Ukrainian Research Institute of metals (UkrNIIMet) are considered. The institute was established in October 30, 1928 to provide metallurgy industry enterprises with scientific \& technological aid. During 90 years institute has being on the advanced front lines of metallurgy, improving existing and developing new efficient technologies for all metallurgy production stages. Currently, UkrNIIMet is a part of SE "UkrRTC "Energostal" and keeping the long-standing traditions alive, pointed at new projects successful implementation in the field of metallurgical manufacturing, energy \& resource saving, waste energy using and environmental protection as well.

Key words: ferrous metallurgy, steel, cast iron, steel continuous casting, elements of the track toplevel structure, rolled steel shapes, grinding bodies, standardization.

Поступила 27.09.2018

УДК 669.1:33(477)

С. Г. Грищенко /Д. Т. н./

Л. Г. Тубольцев /к. т. н./

НТС ОП «Укрметаллургпром», г. Киев, Украина Институт черной металлургии НАН Украины, г. Днипро, Украина

А. Ф. Гринев /к. т. н./ ООО «Укрметаллургинформ «НТА», г. Днипро, Украина

\title{
Позитивные аспекты развития металлургии Украины
}

S. G. Grishchenko /Dr. Sci. (Tech.)/

L. G. Tuboltsev /Cand. Sci. (Tech.)/

A. F. Grinev /Cand. Sci. (Tech.)/
Scientific and Technical Council of the Ukmetallurgprom, Kyiv, Ukraine Institute of Ferrous Metallurgy of the National Academy of Sciences of Ukraine, Dnipro, Ukraine LLC “Ukrmetallurginform” NTA”, Dnipro, Ukraine

\section{Positive aspects of the development of metallurgy of Ukraine}

Цель. Определение аспектов развития черной металлургии как базовой отрасли экономики Украины.

Методика. Анализ открытых литературных источников и информации о состоянии и работt черной металлураии.

Результаты. Отмечено, что развитие черной металлургии всегда являлось важнейшей функцией государства, даже в условиях полной приватизации металлургических предприятий. Показано, что произ-

○ С. Г. Грищенко /Д. т. н./, Л. Г. Тубольцев /к. т. н.І, А. Ф. Гринев /к. т. н./, 2018 г. 
водственные показатели и вклад черной металлургии в экономику страны в значительной степени определяются законодательной политикой государства и согласованной работой взаимосвязанных отраслей промышленности. Отмечено, что перспектива развития металлургии Украины на современном этапе связана с организацией творческого взаимодействия металлургических предприятий с отечественными учеными.

Научная новизна. Обоснование законодательных и научно-технических направлений развития металлургии Украины.

Практическая значимость. Приведены предложения по усилению взаимодействия металлургических предприятий с отечественными научными, проектными организациями и вузами для разработки программы технического перевооружения и модернизации металлургического производства. (Ил. 4. Библиогр.: 13 назв.)

Ключевые слова: черная металлургия Украины, производственные показатели, законодательная политика, модернизации металлургического производства.

Горно-металлургический комплекс Украины (ГМК) является важнейшей базовой отраслью, от которой зависит не только успешная работа экономики страны, но и ее национальная безопасность. В этой связи постараемся обратить внимание на положительные аспекты работы отрасли, которые определяют перспективу ее развития.

История вопроса. Во второй половине XX ст. в Украине был создан мощный комплекс металлургических предприятий, соответствующий ему научный потенциал научно-исследовательских и проектно-конструкторских институтов металлургического профиля. В составе бывшего Союза Украина производила более 40 \% общей продукции черной металлургии. Украинская наука играла важную роль в создании и внедрении металлургических технологий. Впервые в мировой практике усилиями украинских ученых были доказаны перспективность и преимущества строительства крупных доменных печей. Впервые в мировой практике на комбинате Криворожсталь была построена крупнейшая в мире доменная печь объемом $5000 \mathrm{~m}^{3}$. Отечественные научные разработки позволили реализовать в доменном производстве альтернативные источники энергии, в частности: пылеугольное топливо, коксовый газ и газифицированные виды топлива, что и сегодня обеспечивает экономию кокса до 20 \%. Первый в мире кислородный конвертер, первая установка десульфурации чугуна в промышленных масштабах, прокатный стан бесконечной прокатки были созданы и введены в строй в Украине. Впервые в мировой практике в Украине была разработана и реализована энергосберегающая технология термического упрочнения проката с использованием тепла прокатного нагрева. Все эти и другие разработки являются основой технологий, широко используемых и сегодня в мировой практике.

Однако сегодня технический уровень отечественной металлургии, даже после реконструкции металлургиче- ских агрегатов, не всегда позволяет конкурировать с новыми современными металлургическими предприятиями, которые активно создаются в мире. В результате вопросы модернизации технологий остаются одной из болевых точек украинской металлургии. Переход на рыночные отношения в условиях жесткого характера мирового рынка и политическая нестабильность в стране привели к нестабильной работе металлургического комплекса и существенным колебаниям уровня производства стали в течение последних лет (рис. 1). Поэтому в период 1990-1994 гг. в ГМК произошло резкое падение объемов производства металлопродукции. Благодаря вниманию и позитивной роли государства с 1995 г. ГМК начал постепенно наращивать объемы производства. В период 1995-2011 гг. Верховной Радой была принята Концепция развития горно-металлургического комплекса, начата работа над Национальной программой развития ГМК, Кабинетом Министров утверждена Государственная программа развития ГМК до 2011 г., принят закон об экономическом эксперименте в ГМК и разработан целый ряд законодательных документов, позволивших стабилизировать работу базовой отрас-

Баланс готового проката в Украине, млн.т

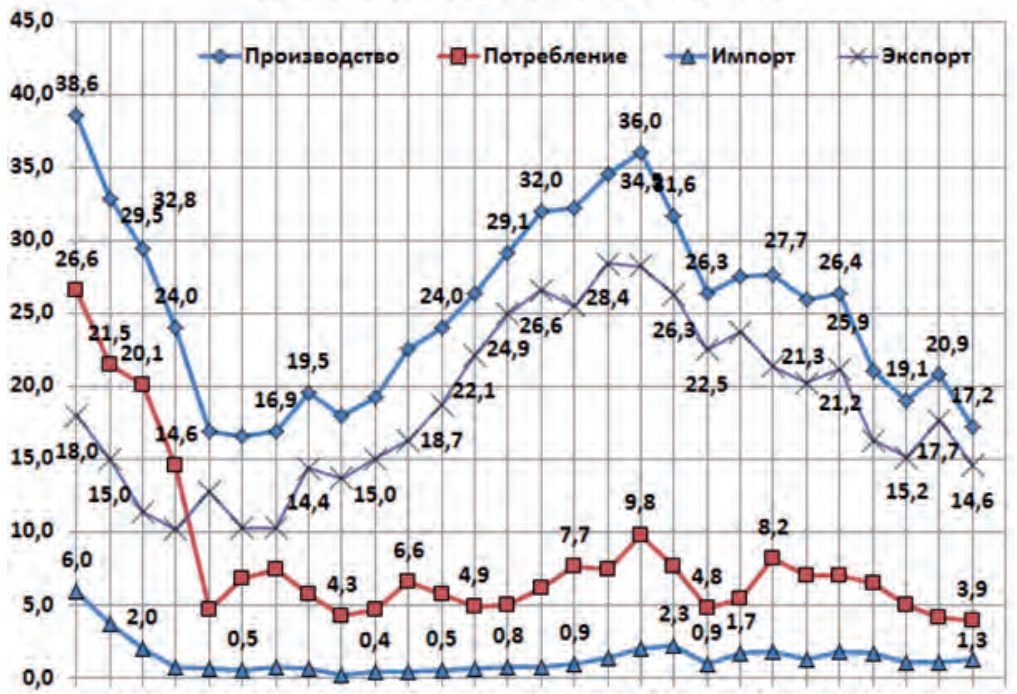

199019921994199619982000200220042006200820102012201420162018

Рис. 1. Динамика производства, потребления, экспорт и импорт готового металлопроката в Украине за 1990-2017 гг. 
ли страны [1; 2]. Отличительной особенностью принятых законодательных документов являлось отсутствие прямой государственной финансовой поддержки ГМК, что позволило успешно отразить все попытки антидемпинговых расследований из-за рубежа.

В период реализации государственного программного подхода в 2004-2011 гг. в черную металлургию удалось привлечь более 20 млрд грн инвестиций, что позволило получить годовой экономический эффект более 5,5 млрд грн за счет снижения уровня материальных и энергетических затрат, расширения производства новых видов продукции. Энергоемкость готового проката за этот период уменьшилась на $13 \%$ - с 1,54 до 1,34 т условного топлива на тонну проката. При этом затраты бюджетных средств на выполнение мероприятий программы и ее научно-техническое сопровождение составили менее 0,1 \%.

Под влиянием внешних и внутренних факторов, начиная с мирового финансового кризиса 2008 г., ГМК находится в более сложном положении, чем в период 1990-1994 гг., что привело к падению производства металлопродукции и нестабильной работе отрасли. С 2011 г. металлургическая отрасль не избалована вниманием государства, ликвидировано Министерство промышленной политики, не утверждаются программы развития ГМК, отсутствуют, даже номинально, правительственные структуры и их подразделения, которые хотя бы интересовались положением дел в одной из важнейших базовых отраслей страны. В то же время в качестве позитивного момента следует отметить попытки металлургов не допустить полного развала отрасли и создать условия для ее перспективного развития.

\section{Роль ГМК в экономике Украины}

Горно-металлургический комплекс Украины является важнейшей стратегической отраслью страны. Например, в структуре перевозок ПАО «Укрзализныця» грузы аграриев занимают 11-12 \%, а грузы ГМК - более 42 \%. В объеме перевалки в морских портах грузы ГМК занимают 44 \%. Экономический эффект от работы ГМК является определяющим для всей экономики Украины. За последние 10-12 лет четко видна тенденция - растет производство продукции ГМК растет экспорт, растет ВВП.

На долю черных металлов в начале 2000-х годов приходилось 30 \% общего товарного производства и 40 \% валютной выручки страны. Украина прочно занимала 7-8-е места в перечне наиболее развитых металлургических стран мира. В 2017 г. мы заняли 12-е место (в 2016 г. - 24,2 млн т, 10-е место), видимое потребление составило 4,5 млн т (4,3 млн т.), при этом потребление на одного человека достигло 101,5 кг (в 2016-м - 96 кг/чел.). В рейтинге экспортеров металлопродукции Украина в 2016-2017 гг. заняла четвертое место в мире. Несмотря на провальный 2017 г. по объемам производства, ГМК сохранил почти треть в структуре украинского экспорта. При производстве проката в 2017 г. менее 17,2 млн т доля металлопродукции в украинском экспорте составила $22 \%$, а вместе с железорудным сырьем (ЖРС) - 28 \%. В качестве примера позитивной роли предприятий ГМК в поступлении валюты в экономику страны приведем данные о наиболее крупных украинских экспортерах металлопродукции (рис. 2) [3].

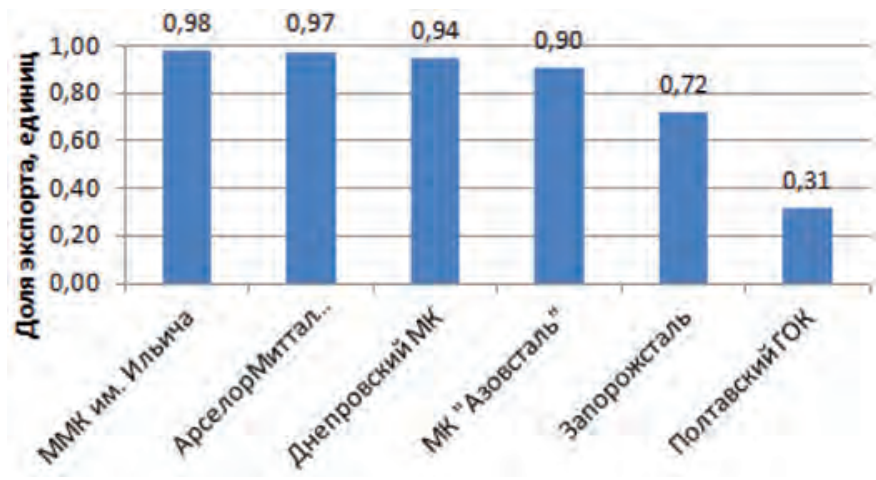

Рис. 2. Крупнейшие экспортеры металлопродукции Украины (2016 г.)

\section{Сырьевая база}

Украина обладает уникальными возможностями для развития черной металлургии и естественными природными ресурсами, имеет собственную железорудную базу и просто обречена быть металлургической страной. По запасам железной руды мы занимаем первое место в мире (16 \% общемировых запасов руды), хотя по содержанию железа украинские руды несколько беднее лучших мировых месторождений [4]. По наличию полезного железа Украина находится на 4-м месте в мире (11 \% общемировых запасов железа) - впереди только РФ (18 \%), Бразилия $(18$ \% ) и Австралия (14\%). Кроме того, в Украине находятся месторождения угля, имеются и необходимые для металлургии водные ресурсы. Компактное расположение металлургических предприятий обеспечено железными дорогами и другой необходимой транспортной системой, включая морские порты.

И хотя по содержанию железа украинские руды уступают австралийским и бразильским, они в состоянии полностью удовлетворить потребности черной металлургии Украины на многие годы. Однако в последние годы металлургические предприятия Украины столкнулись с явлением дефицита практически на все важнейшие виды сырья, в т. ч. и на железную руду, что связано с возрастающим ее экспортом в связи с расширением объемов мирового производства. Ситуация усложнилась также монопольной по- 
зицией производителей железорудного сырья. Горно-обогатительные комбинаты сформировали личные коммерческие интересы, автономные от интересов металлургического сектора, и обросли сбытовыми компаниями, которые работают преимущественно на внешний рынок. По этой причине металлургическим предприятиям пришлось прибегнуть даже к импорту железной руды.

По нашему мнению, экспорт железорудного сырья не имеет перспективы. Анализ показывает, что страны с богатыми природными ресурсами не развиваются и теряют саму возможность перспективного развития [5].

Внутренний рынок и экспорт металлопродукции

В последние годы емкость внутреннего рынка металлопродукции стремительно сокращается (рис. 1). В первые годы независимости Украина выплавляла около 50 млн т стали, при этом внутреннее потребление составляло более 25 млн т металлопроката. В 2017 г. внутреннее потребление проката составило 5,2 млн т, в т. ч. проката украинского производства - 3,9 млн т, импортировано - 1,3 млн т. В 2016 г. 5,4 млн т, 4,2 млн т и 1,1 млн т соответственно. В 2017 г. импорт металлопроката вырос на 0,25 млн т (+23,4 \%), причем половина импорта составляет продукция, производимая на украинских предприятиях. Емкость внутреннего рынка потребления металлопроката в январе - феврале 2018 г. составила 527 тыс. т, из которых 193 тыс. т, или 36,6 \%, приходится на импорт, т. е. при общем снижении емкости внутреннего рынка на 33 \%, объем импортируемого металлопроката вырос почти на 42 \%. Таким образом, проблема внутреннего рынка металлопродукции продолжает обостряться: за январь - февраль 2018 г. поставки украинской металлопродукции составили всего 11,3 \% от общего объема произведенного металлопроката (для сравнения - за аналогичный период 2017 г. украинские металлурги отгрузили отечественным потребителям 20,5 \% объема своей продукции). Все это происходит на фоне одновременного существенного роста металлургического импорта, что в принципе может грозить потерей внутреннего рынка для металлургии Украины. В то же время можно отметить, что при благоприятных условиях развития экономики Украины внутренний рынок металлопроката в ближайшее время может вырасти до 12-15 млн т, а оценка необходимости развития инфраструктуры показывает, что на ближайшие 10 лет Украине может понадобиться около 300 млн т металлопроката, что может полностью загрузить металлургическую отрасль страны [6].

Экспорт заготовки и полуфабрикатов гарантирует определенный уровень загрузки произ- водственных мощностей и работы черной металлургии Украины, хотя глобальные риски по возможности экспорта металлопродукции и железной руды сохраняются в условиях очень большого запаса избыточных металлургических мощностей в мире. Следует отметить, что в прессе было достаточно публикаций о необходимости ограничения экспорта продукции с низкой добавленной стоимостью [7]. В структуре экспорта металлопроката львиная доля приходится на заготовку и полуфабрикаты - в 2017 г. это порядка 40 \% от общего объема экспорта металлургической продукции. В 2018 г. на долю полуфабрикатов приходится 42,9 \%, что несколько ниже показателя аналогичного периода 2017 г. (44,1%). На втором месте плоский прокат. Видовая структура экспорта металлопроката ГМК за 2015-2017 гг. представлена на рис. 3.

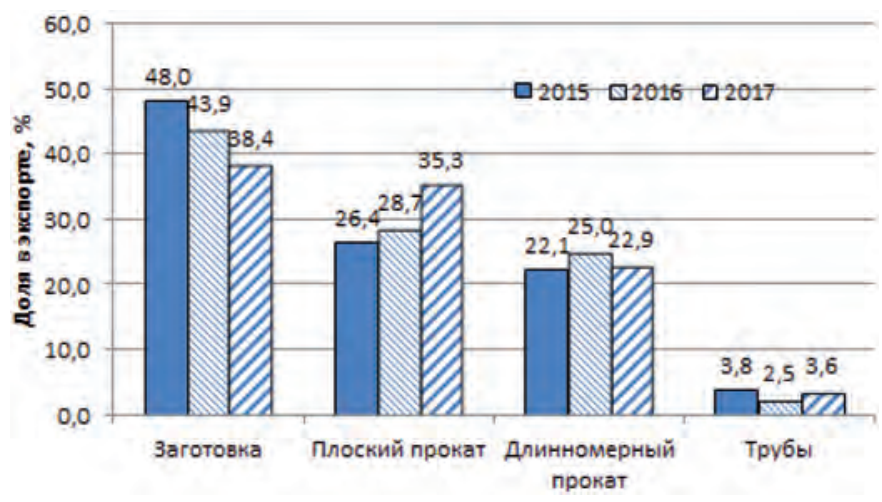

Рис. 3. Видовая структура экспорта металлопроката ГМК, \%

Среди экспортных рынков украинской металлопродукции основными остаются страны Европейского Союза (32,3 \% экспорта), Ближнего Востока (14,3 \%) и прочие страны Европы, включая Турцию (14,0%). В то же время импортируемая металлопродукция на 38,9 \% поступает из СНГ, порядка 26,1 \% из Европейского Союза и 25,6 \% из Азии. Кстати, тенденция к увеличению объемов импортных поставок наблюдается достаточно давно. Так, если в 2015 г. в Украину в течение года было завезено порядка 770 тыс. т металлопроката, в 2016 г. объем увеличился до 1,06 млн т, то в 2017 г. этот показатель составил уже 1,3 млн т. Поэтому необходимо осуществлять защиту отечественного производителя от недобросовестной конкуренции на внутреннем рынке путем распространения антидемпинговых и специальных мер на соответствующий сортамент металлургической продукции. Недавно Минэкономразвития и торговли провело расследование в отношении арматуры и катанки из РФ и ввело пошлины в размере 15,2 \% на продукцию из Таможенного союза. Этот положительный пример показывает, что мы можем защищать внутренний рынок 
от импорта продукции, которая производится в Украине.

Показатели текущего производства металлопродукции

Металлурги Украины в 2017 г. выплавили 21,3 млн т стали, что является самым низким показателем в истории независимой Украины. Показатели экспорта металлопроката также упали до исторических минимумов. Но за счет мирового роста цен ГМК сохранил почти треть ценового вклада в структуре украинского экспорта. Несмотря на потерю части мощностей на неподконтрольной территории в металлургической отрасли наблюдается улучшение показателей работы. В первом полугодии 2018 г. (по сравнению с аналогичным периодом 2017 г.) рост производства составил: агломерата - 106 \%, окатышей - 109, кокса - 106, чугуна - 108, стали - 106, проката - 110, трубной продукции - 109 \% [8]. Это стало возможным благодаря стабилизации обеспечения предприятий железорудным сырьем и коксом, а также вводу в эксплуатацию доменной печи № 3 на МК «Запорожсталь» после реконструкции. Несмотря на увеличение в первом полугодии 2018 г. объемов производства металлопродукции потребление природного газа не увеличилось по сравнению с аналогичным периодом 2017 г., а потребление электроэнергии увеличилось незначительно.

В 2018 г. из основных действующих производственных мощностей в эксплуатации находятся: 18 из 21 доменных печей, 7 из 9 мартеновских печей, 13 из 16 конвертеров, 7 из 15 электропечей и 14 из 14 машин непрерывного литья заготовки.

Для обеспечения коксохимических предприятий коксующимся углем значительная его часть завозится по импорту - около 80 \% от потребности. Сейчас большое количество коксующегося угля завозится из США, Канады, Австралии через морские порты. Импорт угля связан с нарушением логистических потоков, потерей угледобывающих шахт на неподконтрольных территориях. Кстати, это один из факторов, почему не работал Днепровский МК (прекращение поставок кокса из Алчевска). В 2018 г. около 95 \% поставок на металлургические предприятия составляет кокс украинского происхождения, хотя часть кокса завозится по импорту.

\section{Проблемные вопросы работы ГМК}

Как и в других отраслях, проблемы ГМК можно разделить на две составляющие. Для устранения проблем первой части зачастую необходимо принятие только ряда организационных мероприятий на государственном уровне. Другая часть проблем может быть устранена только в течение нескольких лет с привлечением инвестиционных средств для модернизации производства.
Помимо влияния давно сложившихся проблем ГМК, нестабильная работа отрасли и падение производства в последние годы формируется также под влиянием ряда внешних и внутренних факторов, основными из которых являются:

- блокада неконтролируемой территории и потеря ряда расположенных на ней предприятий;

- дефицит металлического лома для металлургических предприятий;

- сложности с инфраструктурой внутри страны, в т. ч. проблемы с тарифами и организацией железнодорожных перевозок; высокие тарифы портовых сборов и высокая стоимость заходов судов в украинские порты (которая остается одной из самых высоких в мире); агрессивные действия РФ в Азовском море;

- колебание и падение цен на металлопродукцию и железорудное сырье в связи с глобальными избыточными мощностями;

- кадровый дефицит вследствие миграции квалифицированных специалистов;

- антидемпинговые расследования и защитные меры промышленно развитых стран мира в отношении металлургической продукции. Металлургические компании отмечают, что их интересы за рубежом никто не защищает - ни Министерство иностранных дел, ни Министерство экономического развития. Для решения этой проблемы, металлургические предприятия предлагают создать Министерство промышленной политики, которое бы лоббировало украинских производителей, создать Экспортно-кредитное агентство (ЭКА) для продвижения продукции украинских производителей на внешних рынках. Предприятия сегодня испытывают большие затруднения с продажей своей продукции из-за дорогих кредитов и закрытости внешних рынков. Для этого почти два года назад был принят закон о создании ЭКА, на сегодняшний день исполнение этого закона правительством отложено.

Согласование работы ГМК с другими отраслями промышленности

Представители крупнейших отраслевых предприятий промышленности обращают внимание па ситуацию, которая сложилась в сфере перевозок грузов железнодорожным транспортом в 2018 г. Вследствие дефицита локомотивной тяги на сети ПАО «Укрзализныця» и отсутствия достаточного количества полувагонов предприятия ГМК системно не выполняют экспортные контракты по поставкам железной руды и металлургической продукции, что крайне негативно влияет на деятельность предприятий, состояние экономики Украины и приводит к потере государством валютной выручки. Только от неэффективной работы ПАО «Укрзализныця» в 2017 г. годовые потери ГМК составили в производстве 
около 2 млн т стали и около 1 млрд дол. валютной выручки.

Металлургические предприятия считают целесообразным и необходимым проводить согласование работы базовых отраслей промышленности на государственном уровне. В числе совместно обсуждаемых мероприятий можно отметить следующие:

- модернизация инфраструктуры страны, в т. ч. проведение работ по углублению морских и речных портов, закупка железнодорожных вагонов, ремонт дорог;

- создание Национального регулятора в сфере транспортных услуг. Этот орган должен разработать методологию, на основе которой упорядочить портовые сборы и железнодорожные тарифы, а также штрафные санкции. Металлургические предприятия настаивают на дальнейшем снижении портовых сборов и не повышении тарифов «Укрзализныци» на перевозку грузов. У морских портов Украины абсолютно неконкурентные ставки портовых сборов, которые более чем в 2,5 раза превышают ставки конкурентов, даже несмотря на 20\%-е снижение с 1 января 2018 г. Металлургические компании волнует, что средства, собранные «Администрацией морских портов» и «Укрзализныцей» с грузовладельцев, не идут на развитие инфраструктуры. При этом почти все сборы в морских портах целевые и должны тратиться на дноуглубительные работы, развитие инфраструктуры портов. Однако этого не происходит.

\section{Влияние государства на работу ГМК}

На стратегию развития металлургии прямое и косвенное воздействие оказывают уровень сотрудничества между промышленностью и правительством [9]. В Украине металлургические предприятия практически полностью приватизированы. О каком государственном влиянии на их работу может идти речь? На этот вопрос дают ответ иностранные эксперты, которые на основании многолетнего опыта утверждают, что сама приватизация ничего не дает, главное - качественное управление и сотрудничество между промышленностью и правительством. Однако все украинские правительства свернули на дорогу приватизации и идут по ней до сих пор, теряя остатки государственного влияния. Результат утрата основ государственного управления базовыми отраслями промышленности, потеря квалифицированных кадров в госуправлении, разрыв производственных и информационных связей между отраслями промышленности. О какой ответственности правительства перед Украиной можно говорить, когда министр экономического развития и торговли заявляет, что его основной задачей является ликвидация его министерства. В подавляющем большинстве развитых стран есть Министерство промышленности и торговли сначала произвести, тогда будет что продать. Кстати о «неэффективности государственного управления», которым обосновывается сплошная приватизация - если политики пекутся об эффективности приватизации, то почему они сами стремятся попасть в неэффективную государственную власть? Крупнейшие промышленно развитые страны никогда не выпускают из сферы государственного влияния базовые отрасли, даже если передают их в частные руки.

В Украине не проводится даже общественное обсуждение проблем и условий развития экономики страны. Принятие на государственном уровне целевой стратегии развития базовых отраслей, в частности черной металлургии, позволит определить ориентиры для развития всей промышленности Украины, сформировать единый подход и к реализации научно-технических достижений.

Одним из системных вопросов, требующих государственного влияния, является развитие внутреннего рынка металлопродукции. Беспрецедентная в мировой практике уязвимость черной металлургии Украины с её несовременной структурой производства и работой преимущественно на экспорт (более 80 \% продукции) не может обойтись без участия государства в решении этой проблемы. Для развития внутреннего рынка крайне важно определиться с потребностями металлопотребляющих отраслей на перспективу (машиностроение, транспорт, строительство, ЖКХ и т. д.).

Одной из важнейших задач является повышение конкурентоспособности не только черной металлургии, но и всей промышленной продукции. Этого невозможно достичь без создания современной государственной базы стандартов на уровне мировых образцов.

В мире сегодня существуют и активно используются положительно зарекомендовавшие себя инструменты промышленной политики, направленные на развитие производства, в частности углубление диалога между государством и бизнесом, расширение использования долгосрочных договорных взаимоотношений. Не секрет, что между государственными чиновниками, наукой и бизнесменами нет взаимопонимания и даже диалога вследствие различия стоящих перед ними целевых задач. К числу указанных инструментов можно отнести предоставление госгарантий, использование программно-целевого подхода к развитию отдельных жизненно важных отраслей, прозрачная ценовая политика, поддержка собственных товаропроизводителей, использование практики обнуления импортных пошлин и НДС 
на технологическое оборудование, что помогает привлекать инвестиционные ресурсы, и многое другое. Важным моментом является создание Стратегии развития промышленности страны, что позволяет не только планировать долгосрочное развитие государства, но и осуществлять госконтроль за реализацией запланированных показателей экономического развития страны.

Для усиления влияния государства на работу ГМК предлагается:

- разработка целевой стратегии развития промышленности страны [10];

- разработка логистики доставки в Украину сырья для металлургии, которое в настоящее время является дефицитным, в т. ч. энергетического и коксующегося угля, кокса. У нас большая доля их импорта. Если на коксохимические предприятия в 2017 г. было поставлено 3,5 млн т украинского сырья, то по импорту было завезено 10,8 млн т из-за прекращения поставок с неконтролируемых территорий Донбасса. Конечно, большая часть углей завозится из России, но сейчас все металлурги активно работают, чтобы заместить эти объемы «морем». Риск транспортировки по Керченскому проливу требует перенаправления грузов на другие порты по железной дороге;

- разработка стратегии использования металлолома в стране. «Укрметаллургпром» совместно с Ассоциацией «УАВтормет» работает над принятием ряда законопроектов по детенизации рынка лома. В январе был зарегистрирован законопроект № 7497 соавторства 18 депутатов, поддержавших ряд инициатив, которые позволят вывести рынок лома из тени (около 70 \% рынка заготовки лома сейчас находится в тени). Несмотря на то, что уже второй год действует повышенная ставка экспортной пошлины на металлолом в размере 30 евро/т, а обеспечение потребностей меткомбинатов в 2017 г. возросло до 90 \% (на меткомбинаты поставлено 3,3 млн т лома), экспорт из Украины растет. В 2017 г. экспорт лома составил 487 тыс. т, что на 76 \% превышает уровень 2016 г. Но, с другой стороны, это показывает то, что пошлина в 30 евро не является заградительной. На 2018 г. потребность ГМК в металлоломе составляет 3,65 млн т;

- разработка стратегии развития внутреннего рынка металлопродукции;

- принятие мер к недопущению антидемпинговых расследований. Четко прослеживается тенденция: если мировой рынок растет и цены идут вверх, то количество антидемпинговых споров уменьшается. И это потому, что правительства (это относится и к развитым, и развивающимся странам) понимают, что ситуация кризисная и приходится защищать собственные рынки, даже если для этого нет повода.
- создание и реализация промышленной политики базовых отраслей промышленности. В этом отношении ГМК может явиться очень хорошим примером: отрасль частная, но государство принимает решения по фискальной политике (рентные платежи), по тарифной политике (монополии на газ, транспортировку газа, электроэнергию, портовые сборы), природоохранной политике, торговой политике (защита рынка). Эти вопросы находятся в сфере Минфина, Минэнергоугля, Мининфраструктуры, но должен быть единый координирующий орган. Сейчас эти функции возложены на МЭРТ, но пока ведомство с этой ролью не справляется. Уже давно назрела необходимость возрождения Министерства промышленной политики;

- создание условий для прекращения оттока рабочей силы. Уезжают лучшие кадры. Сейчас эта тенденция приняла лавинообразный характер. Люди уезжают, потому что в Европе более стабильная ситуация.

В промышленно развитых странах правительства никогда не остаются в стороне от ситуации, складывающейся в черной металлургии [9]. В частности в Китае существует система поощрений и наказаний для предприятий. Компании, которые полностью соответствуют установленным стандартам, в том числе экологическим, технологическим, требованиям качества, энергосбережения, производительности, получают от государства дополнительные дотации, а также снижение пошлин на перевозки по территории страны. Европейский Союз старается разработать план, который позволит улучшить состояние металлургической промышленности, в т. ч. за счет модернизации технологий и производств, сокращения производства стали и закрытия предприятий. В Японии пошли совершенно другим путем - основные капиталовложения были направлены на строительство новых предприятий с применением самых новейших на тот период технологий, что позволяет ей удерживать лидирующее положение в мировой промышленности. Особое внимание уделяется научно-техническим исследованиям, при этом отчисления в развитие инновационных технологий достигают 5 \%.

ГМК не рассчитывает на финансовую государственную поддержку, однако законодательная поддержка работы отрасли крайне необходима. В качестве позитивных моментов возможной государственной поддержки можно отметить следующие аспекты:

- мониторинг работы отрасли и согласование вопросов развития отрасли с другими государственными и приватизированными отраслямимонополиями для достижения позитивного результата для экономики страны; 
- разработка целевой программы развития Украины для выработки критериев для оценки результатов выполнения программы;

- государственное финансирование научных исследований для перспективного развития базовых отраслей промышленности.

\section{Роль науки в развитии ГМК}

Что же может дать черной металлургии и стране нынешняя металлургическая наука? В качестве примера можно перечислить:

- совершенствование подготовки шихтовых материалов к доменной плавке;

- участие в модернизации доменных печей Украины;

- совершенствование и создание новых технологий загрузки и плавки для доменных печей, в том числе с использованием пылеугольного топлива;

- совершенствование технологии кислородно-конвертерной плавки, внепечной обработки чугуна и стали, непрерывной разливки стали;

- расширение сортамента и номенклатуры готового проката;

- использование термической и термомеханической обработки как средства коренного улучшения механических и эксплуатационных свойств готовой продукции и др.

Экономический эффект от реализации таких технологий может достигать 200 грн на тонну проката.

Понимая необходимость модернизации металлургических технологий, металлургические предприятия в 2017 г., несмотря на тяжелое положение, нарастили инвестиции в техническое перевооружение на 7 \%, до 10,6 млрд грн (426 млн дол.), которые пошли, главным образом, в проекты энергоэффективности, на снижение себестоимости, природоохранные мероприятия (рис. 4). К сожалению, не все металлургические предприятия отрасли проводят работы по модернизации производства.

Однако взаимодействие приватизированных металлургических предприятий с научными организациями весьма ограничено. Разобраться

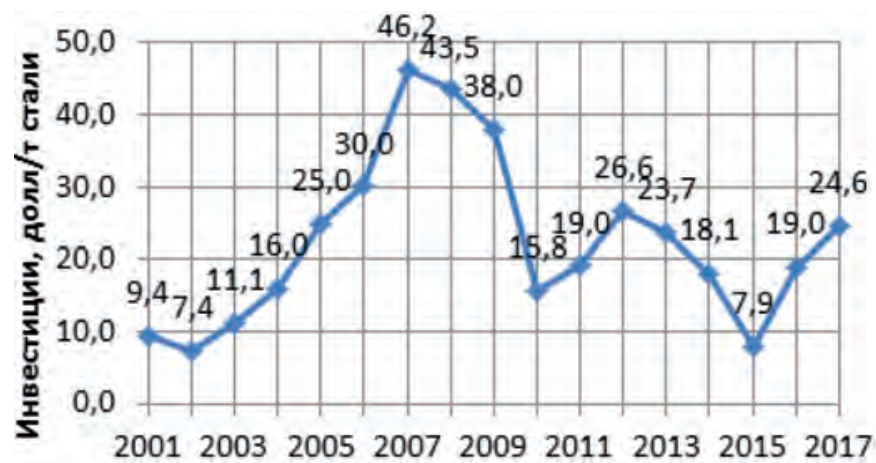

Рис. 4. Инвестиции в ГМК Украины на техническое перевооружение и модернизацию металлургических технологий с этим явлением крайне сложно, поскольку отсутствие тесного взаимодействия связано как с объективными, так и субъективными причинами. Но еще в 1878 г. известный ученый-металлург И. А. Тиме писал: «Частные заводы... ведут... особую замкнутую жизнь, и доступ в них молодежи, свежим силам сопряжен с такими трудностями, которые нередко равносильны запрещению» [11]. И в Украине приватизированные предприятия нередко относят к коммерческой тайне самую примитивную информацию о производстве, что не позволяет ученым объективно оценивать технологический уровень производства. Так что история повторяется!

Анализируя информацию из литературных источников, невольно отмечаешь, что достижения металлургических предприятий за рубежом напрямую связаны с совместной работой производственников и ученых. Об этом открыто заявляют авторы статей из Германии, Японии, США. Об этом говорит и опыт работы металлургических предприятий во времена Советского Союза, когда наука широко внедряла свои разработки в производство. Ориентация украинских предприятий только на использование зарубежных технологий и оборудования уже приводит к отставанию технического уровня производства, поскольку нам продают уже устаревшие технологии. В то же время украинская металлургическая наука и сегодня располагает разработками, позволяющими существенно повысить технический уровень металлургического производства в Украине и довести его до уровня лучших мировых достижений [12].

Следует отметить, что из-за ограниченного доступа к реальным объектам промышленности отечественных ученых в значительной мере ограничиваются потенциальные возможности практической реализации передовых достижений украинской науки. Потеря тесного взаимодействия науки с производством не позволяет реализовать в Украине многие проекты, которые в то же время привлекательны для зарубежных потребителей. Восстановление координационной деятельности министерств и роли головных научно-исследовательских институтов в отраслях промышленности может усилить формирование научно-технической политики развития предприятий. Одним из путей решения этой проблемы является создание механизма обязательного привлечения научно-исследовательских институтов и НАН Украины к проведению экспертизы инновационных проектов, предлагаемых для реализации на промышленных предприятиях страны.

Опыт промышленно развитых передовых стран показывает, что для превращения науки в реальную производственную силу объем ее финансирования должен быть не менее 1,7-2 \% ВВП. Ряд стран доводят этот показатель до 3-5 \%. 
В Украине объем финансирования научных исследований едва достигает 0,17 \% ВВП, что при скромном бюджете страны не позволяет даже сохранять накопленный научный потенциал.

\section{Кадры}

Нехватка рабочей силы «...является величайшим вызовом... и ....может стать самым серьезным сдерживающим фактором для экономики Германии», - заявила канцлер ФРГ. Это же можно сказать и относительно Украины. В последние годы в ГМК все больше ощущается дефицит рабочей силы. Еще несколько лет назад предприятия проводили существенное сокращение персонала. Сейчас специалисты уезжают за границу на постоянную работу, и этот процесс принял лавинообразный характер. Связано это с нестабильной ситуацией, с более низким уровнем жизни и заработной платы в Украине. Украина находится в состоянии военного конфликта.

Из-за отсутствия в Украине политики подготовки кадров и специалистов для металлургической отрасли, снижения престижности высшего образования технической направленности, отсутствия надежной перспективы трудоустройства и работы по специальности резко снизилась подготовка инженеров-металлургов и научных работников. Исчезает подготовка необходимых металлургическим предприятиям специалистов, в том числе из-за уменьшения бюджетного финансирования необходимых специальностей. Для решения проблем высшего металлургического образования и подготовки научных кадров необходима поддержка металлургических предприятий и крупных компаний, поскольку это определяет и перспективу развития предприятий. Здесь возможны различные формы взаимодействия вузов с предприятиями, в т. ч. заключение контрактов между студентами и предприятиями, целевая подготовка выпускников вузов на конкретном рабочем месте, восстановление годичной практики студентов технических специальностей на рабочих точках металлургических предприятий, чередование академического и производственного обучения.

Для подготовки научных кадров, которая требует 10-15 лет профессиональной подготовки, необходима тесная работа металлургических предприятий с научно-исследовательскими и проектно-конструкторскими институтами, которой в настоящее время препятствуют опасения недобросовестной конкуренции и чрезмерная защита бизнес-интересов. Однако это вполне решаемые вопросы, в т. ч. на конфиденциальном уровне.

Стремительные темпы мирового научно-технического прогресса в ближайшее время заставят и украинские металлургические предприятия теснее работать с научными организациями.

\section{Выводы}

Проведенный анализ показал, что в ГМК нет нерешаемых проблем системного характера, которые могут препятствовать успешному и экономически целесообразному развитию отрасли. Итоги за 9 месяцев 2018 г. показывают положительную динамику работы отрасли по сравнению с аналогичным периодом прошлого года - производство агломерата увеличилось на 5 \%, окатышей - на 9, кокса - на 6, чугуна - на 11, стали - на 5, проката на 8, трубной продукции - на 6 \% [13]. Прогнозируется дальнейшая стабилизация производства металлургической продукции. Прогноз на 2018 г. показывает, что выплавка стали может увеличиться на $8 \%(7,6-9,4 \%)$ и составит 22,5-23,3 млн т.

Можно констатировать, что на данном этапе стабилизация работы ГМК и его модернизация вполне возможна и реальна. При этом следует обратить внимание на реализацию следующих аспектов:

- восстановить координирующую и законодательную роль государства в развитии украинской металлургии, в том числе на уровне создания Стратегии целевого развития металлургии в рамках общего развития промышленности;

- создать Министерство промышленной политики и Экспортно-кредитное агентство (ЭКА) для возможности лоббирования и продвижения продукции украинских производителей на внешних рынках;

- на законодательном уровне стимулировать направление сырьевых ресурсов станы на глубокую переработку и производство продукции с максимально возможной добавочной стоимостью;

- рекомендовать металлургическим и проектно-конструкторским предприятиям усилить взаимодействие с отечественными научными, проектными организациями и вузами для реализации научно-технических достижений в производстве, подготовки научных кадров и специалистов-металлургов с целью перспективного развития предприятий;

- систематически проводить на металлургических предприятиях встречи заводских специалистов с представителями отечественных научных организаций и вузов для разработки программы технического перевооружения и модернизации металлургического производства.

\section{Библиографический список / References}

1. Большаков В. И. Технический уровень и научное сопровождение металлургической отрасли Украины / В. И. Большаков, Л. Г. Тубольцев, А. Ф. Гринев / / МГП. - 2011. - № 2. - С. 1-6.

Bol'shakov V. I., Tubol'tsev L. G., Grinev A. F. Tekhnicheskiy uroven' i nauchnoe soprovozhdenie metallurgicheskoy otrasli Ukrainy. MGP. 2011, no. 2, pp. 1-6. 
2. Украинская металлургия: современные вызовы и перспективы развития: монография / А. И. Амоша, В. И. Большаков, Ю. С. Залознова и др. - Донецк: Институт экономики промышленности НАН Украины, 2013. - 113 с.

Amosha A. I., Bol'shakov V. I., Zaloznova Yu. S. Ukrainskaya metallurgiya: sovremennye vyzovy $i$ perspektivy razvitiya. Donetsk, Institut ekonomiki promyshlennosti NAN Ukrainy, 2013, 113 p.

3. https:// delo.ua/business/top-10-krupnejshiheksporterov-ukrainy-kto-stal-liderom-v-2016-g337155/

4. Зиновьева Н. Г. Обзор мирового рынка железной руды (Сообщение 1) / Н. Г. Зиновьева // Бюллетень научно-технической и экономической информации. Черная металлургия. - 2015. Вып. 9. - С. 3-7.

Zinov'eva N. G. Obzor mirovogo rynka zheleznoy rudy (Soobshchenie 1). Byulleten' nauchnotekhnicheskoy i ekonomicheskoy informatsii. Chernaya metallurgiya. 2015, issue 9, pp. 3-7.

5. http://emchezgia.ru/syrye/6.1_mestorozhdeniya_ zheleznyh_rud_v_mire.php

6. https://zn.ua/author/vladimir-vlasyuk

7. Большаков В. И. Научно-технические приоритеты металлургического комплекса / В. И. Большаков, Л. Г. Тубольцев, А. Ф. Гринев // Металлургическая и горнорудная промышленность. - 1998. - № 1. - С. 1-2.

Bol'shakov V. I., Tubol'tsev L. G., Grinev A. F. Nauchno-tekhnicheskie prioritety metallurgicheskogo kompleksa. Metallurgicheskaya i gornorudnaya promyshlennost'. 1998, no 1, pp. 1-2.

8. https:/ / seosait.com/dinamika-vvp-mira- 19702016/1

9. Норихико Судзуки. Innovations and management in the japanese corporation. - Published by Industrial Engineering and Management Press Institute ol Industrial Engineers, 2000.

Norikhiko Sudzuki. Innovations and management in the japanese corporation. Published by Industrial Engineering and Management Press Institute ol Industrial Engineers, 2000.

10. Большаков В. И. Нужна ли Украине стратегия развития черной металлургии? / В. И. Большаков, Л. Г. Тубольцев // Зеркало недели. Украина. - 2015. - № 21, 12 июня.

Bol'shakov V. I., Tubol'tsev L. G. Nuzhna li Ukraine strategiya razvitiya chernoy metallurgii? Zerkalo nedeli. Ukraina. 2015, no. 21, June 12.

11. Тиме И. А. Горный журнал. - 1978. - Т. 1, № 3. - C. 204-229.

Time I. A. Gornyy zhurnal. 1978, vol. 1, no. 3, pp. 204-229.

12. Babachenko A. I. Scientific and technical support of black metallurgy / A. I. Babachenko, L. G. Tuboltsev / / Фундаментальные и прикладные проблемы черной металлургии. Сб. науч. тр. ИЧМ. - 2017. - № 31. - С. 3-9.
13. https:/ / ukrmet.dp.ua/2018/09/17/ukrainaitogi-raboty-gorno-metallurgicheskogo-kompleksagmk-v-yanvare-avguste-2018-goda.html

Мета. Визначення аспектів розвитку чорної металургії як базової галузі економіки України.

Методика. Аналіз відкритих літературних джерел та інфрормації про стан і роботу чорної металураії.

Результати. Відзначено, що розвиток чорної металургії завжди був найважливішою функцією держави, навіть в умовах повної приватизації металургійних підприємств. Показано, що виробничі показники і внесок чорної металургії в економіку країни значною мірою визначаються законодавчою політикою держави і узгодженою роботою взаємопов'язаних галузей промисловості. Відзначено, що перспектива розвитку металургії України на сучасному етапі пов'язана з організацією творчої взаємодії металургійних підприємств з вітчизняними вченими.

Наукова новизна. Обгрунтування законодавчих та науково-технічних напрямів розвитку металургії України

Практична значущість. Наведено пропозиції щодо посилення взаємодії металургійних підприємств з вітчизняними науковими, проектними організаціями $i$ ВНЗ для розробки програми технічного переозброєння і модернізації металургійного виробництва.

Ключові слова: чорна металургія України, виробничі показники, законодавча політика, модернізація металургійного виробництва.

Purpose. Defining aspects of the development of ferrous metallurgy as the basic sector of the Ukrainian economy.

Methodology. Analysis of open literature and information on the status and operation of the steel industry.

Findings. It was noted that the development of ferrous metallurgy was the most important function of the state even in the conditions of full privatization of metallurgical enterprises. It is shown that the production indicators and the contribution of the steel industry to the country's economy are largely determined by the legislative policy of the state and the coordinated work of interrelated industries. It was noted that the prospect of the development of metallurgy of Ukraine is associated with the organization of the creative interaction of metallurgical enterprises with domestic scientists.

Originality. Justification of legislative, scientific and technical directions of development of metallurgy of Ukraine

Practical value. There are proposals to strengthen the interaction of metallurgical enterprises with domestic scientific, design organizations and universities to develop a program for the modernization of metallurgical production.

Key words: ferrous metallurgy of Ukraine, production indicators, legislative policy, modernization of metallurgical production.

Рекомендована к публикации Ә. т. н. В. Ф. Балакиным Поступила 28.09.2018 